\author{
J. S. Siphepho \\ M.Cur Psychiatric Nursing \\ RAU
}

$\&$

\section{A.C. Gmeiner}

D.Cur Psychiatric Nursing RAU

\section{Ahstract}

A number of adolescents have been observed drinking alcohol, pushing and abusing drugs and also stealing cars. A lot of adolescents idle in the township streets, girls are falling pregnant and dropping out of school. No research has been done to elicit the opinions of families on the everyday life of the adolescents in this township. The objectives of this research were twofold, namely:

To explore and describe the families' opinions on the everyday life of adolescents in a specific township in Swaziland, and to describe guidelines for advanced psychiatric nurse practitioners to assist these families to mobilize resources in order to promote, maintain and restore mental health as integral part of health of adolescents in this township.

A qualitative, exploratory, descriptive and contextual design was used where the research was conducted in two phases. Trustworthiness measures as well as ethical measures were applied throughout the research.

Five categories were identified from the result of the focus group interviews with families: Adolescents presenting ineffective communication patterns due to lack of support from their families; adolescents engaging into risky lifestyles related to lack of support and healthy relationships with their parents; families unable to create a supportive and conducive environment for their adolescents due to their focus on own family stumbling blocks and non-availability of recreational centres related to lack of a supportive and conducive environment in the community and inadequate accommodation leading to overcrowding. Guidelines for advanced psychiatric nurse practitioners were deducted from identified themes and the literature control.

\section{Opsomming}

\section{“... city families are often large, poor and of low social status."}

Dit is waargeneem dat ' $n$ aantal adolessente in ' $n$ sekere plakkerskamp in Swaziland alkohol en dwelms misbruik en motors steel. Baie van hierdie adolessente dwaal in die strate rond, meisies raak swanger en verlaat die skool. Geen navorsing is gedoen om te bepaal wat die opinie van gesinne oor die alledaagse lewe van die adolessente in die spesifieke plakkerskamp is nie. Die doelstellings van die navorsing was tweeledig, naamlik:

Om die gesinne se opinie van die adolessente se alledaagse lewe te verken en te beskryf, en om riglyne vir die gevorderde psigiatriese verpleegpraktisyn te beskryf om hierdie gesinne by te staan in die mobilisering van hulpbronne om hierdie adolessente se geestesgesondheid te bevorder, te handhaaf en te herstel.

' $n$ Kwalitatiewe, verkennende, beskrywende en kontekstuele ontwerp is gevolg waar die navorsing uitgevoer is in twee fases. Vertrouenswaardigheidstrategieë, sowel as etiese maatreëls is deurentyd streng toegepas.

Vyf kategorieë is geidentifiseer: Adolessente presenteer oneffektiewe kommunikasiepatrone te wyte aan 'n gebrek aan ondersteuning van hul gesinne; adolessente betrokke in riskante lewenstyle te wyte aan 'n gebrek aan ondersteuning en gesonde verhoudings met hul ouers; gesinne se onvermoë om 'n ondersteunende omgewing vir hul adolessente te skep omdat hulle sterk fokus op hul eie gesinstruikelblokke en die nie-beskikbaarheid van ontspanningsentra te wyte aan die omgewing in die gemeenskap wat nie-bevorderlik en nie-ondersteunend is. Ontoereikende behuising lei verder tot oorbevolking. Riglyne vir die gevorderde psigiatriese verpleegpraktisyn is geidentifiseer uit bogenoemde temas en literatuur kontrole. 


\section{Background and}

\section{Rationale}

The efforts of families to mobilise resources to promote, maintain and re store the mental health of adolescents, especially in cities of certain poor countries are usually distracted and/or retarded by a number of mental health problems. According to Desjarlais, Eisenberg, Good and Kleinman (1995:134) wars, prolonged conflicts ethnic discord and state repression often lead to a flood of social, economic and psychological problems undermining wellbeing. Similarly, mental health services in many poor countries are severely limited in terms of finances and potential manpower, hence putting at risk the mental health of adolescents.

It therefore follows that the mental health of adolescents subjected to city life are subjected to many risk factors, hindering families to mobilise the available resources to promote, maintain and restore the mental health of adolescents. These circumstances usually pose a serious threat to the everyday life of the adolescents. Quinton (1991:15) supporting this states: "... city families are often large, poor and of low social status." According to Quinton (1991:15) many of the families are headed by single mothers or unemployed fathers, consequently putting the mental health of adolescents at serious risk as they live in overcrowded or poor quality conditions. Since adolescents spend a better part of their everyday life with their families, families need to be assisted to adequately and relevantly respond to the everyday life needs of the adolescents (Kaplan et al, 1994:51-56).

\section{Problem Statement and Objectives}

The researcher comes from a township situated in the suburbs of a city in Swaziland. As a resident of the township the researcher has observed a number of families faced with difficulties regarding the mobilisation of available resources to promote, maintain and restore the mental health of adolescents. The township does not have programmes to assist the families to mobilise the available resources to promote, maintain and restore the mental health of adolescents. Some of the adolescents have been observed drinking alcohol, pushing and abusing drugs and also stealing cars. Adolescents, when drunk, become violent and aggressive towards other people as well as their parents/guardians and/or relatives. The majority of families in the township are poor. Among the people living in the township are adolescents who go to the city looking for work. This results in a lot of adolescents idling in the township streets. Christopher Masuku, a parliamentarian in the township stated: “... we are having a serious problem concerning the adolescents in the township. Young girls are falling pregnant and dropping out of school. Boys are pushing and/ or abusing drugs. Parents are complaining about their adolescents, who do not respect them."

No research has been conducted to explore and describe the opinions of family members and the following research question was asked: "What are the opinions of families on the everyday life of adolescents and what guidelines can be described for advanced psychiatric nurse practitioners to assist families to mobilise resources to promote, maintain and restore the mental health of adolescents?"

The objectives of this research therefore were two-fold:

- To explore and describe families' opinions on the everyday life of adolescents.

- $\quad$ To describe guidelines for the advanced psychiatric nurse practitioner to assist the families to mobilise the available resources to promote, maintain and restore the mental health of adolescents.

\section{Paradigmatic Perspective and Research Model}

Botes's (1991:19) research model was utilised as point of departure for this research. The central theme of this model is that research should be functional, namely that nursing research should be undertaken in order to improve nursing practise.

This research was based on the assumptions of the Nursing for the Whole Person Theory (Oral Roberts University: Anna Vaughn School of Nursing, 1990:136-142). This paradigm focuses on all the dimensions of the whole person, i.e. body, mind and spirit in his/her internal and external environments. This paradigm also infers that the adolescent is a spiritual and integrated bio-psychosocial being, functions in a holistic manner within the family and/or community (Siphepho, 1999:5-7).

\section{Research design and method}

A qualitative, exploratory, descriptive and contextual design was utilized (Mouton \& Marais, 1990:43-44; Burns \& Grove,
1993:28-29), since the researcher wanted to generate an in-depth account that would present a lively picture of the research respondents' reality within the family context (Holloway \& Wheeler, 1996:2-3).

This research was carried out in two phases. In phase one the families' opinions on the everyday life of the adolescents were explored and described Data was gathered by means of in-depth focus group interviews (Denzin \& Lincoln, 1994:364-365) with families in the township that met the sampling criteria of this research. One central question was asked and non-directive communication techniques used. These focus group interviews were taped and transcribed verbatim. Field notes were also taken (Wilson, 1989:343) to obtain supportive information and as a system for remembering observations during focus group interviews.

Data was analyzed by means of the descriptive method of analysis by Tesch (in Creswell, 1994:155). Following the completion of data analysis, the literature from relevant and similar studies was used to recontextualise the data and to identify similarities and differences between the findings of this research and other related research.

In the second phase data from phase one and the literature control was used to deduct and describe guidelines for the advanced psychiatric nurse practitioner to assist families to mobilise the available resources in order to promote, maintain and restore the mental health of adolescents. These guidelines were discussed with advanced psychiatric nurse practitioners to verify its appropriateness. A literature control was done to enrich the guidelines and for verification.

\section{Sampling}

Members of a family whose adolescents have been observed engaging in delinquent behaviour will form the sample in this research. This means that focus group interviews will be conducted among and with members of each and every family that meet the sampling criteria for a number of families until data is saturated (Morse, 1994:104). Purposive sampling will be used in this research (Polit \& Hungler, 1995:235). Sampling criteria included:

- $\quad$ Parents, guardians and relatives of adolescents.

- The guardians and relatives should have been with the adolescents for at least five years. They should all speak Siswati, Zulu and/or English, because 


\section{Table 1 Results of focus groups electing the opinions of family members and parents on the everyday life of adolescents}

\begin{tabular}{|c|c|c|}
\hline Main theme & Categories & Subcategories \\
\hline \multirow[t]{5}{*}{$\begin{array}{l}\text { 1. Disrupted adolescents' life related to } \\
\text { lack of a supportive and conducive en- } \\
\text { vironment in the family and community. }\end{array}$} & $\begin{array}{l}\text { 1.1Adolescents presenting ineffective } \\
\text { communication patterns due to lack of } \\
\text { support from their families. }\end{array}$ & $\begin{array}{l}\text { Ineffective communication patterns of- } \\
\text { ten lead to: } \\
\text { - Destructive curiosity } \\
\text { - Stubbornness } \\
\text { - Aggression } \\
\text { - Dangerous pride }\end{array}$ \\
\hline & $\begin{array}{l}1.2 \text { Adolescents engaging into risky life } \\
\text { styles related to lack of support and } \\
\text { healthy relationships with their parents. }\end{array}$ & $\begin{array}{l}\text { Risky life styles evidenced by: } \\
\text { - Drug abuse and drug dependency } \\
\text { - Pregnancy, HIV/AIDS, Sexually Trans- } \\
\text { mitted Diseases (STD's) } \\
\text { - Suicidal thoughts }\end{array}$ \\
\hline & $\begin{array}{l}\text { 1.3 Families unable to create a support- } \\
\text { ive and conducive environment for the } \\
\text { adolescents due to their focus on own } \\
\text { family stumbling blocks. }\end{array}$ & $\begin{array}{l}\text { Stumbling blocks in the families being: } \\
\text { - Parental ignorance } \\
\text { - Generation gap } \\
\text { - Influence of mass media communi- } \\
\text { cation. }\end{array}$ \\
\hline & $\begin{array}{l}1.4 \text { Non-availability of recreational cen- } \\
\text { tres related to lack of a supportive and } \\
\text { conducive environment in the commu- } \\
\text { nity. }\end{array}$ & - Idleness and criminal offence \\
\hline & $\begin{array}{l}1.5 \text { Inadequate accommodation related } \\
\text { to lack of a conducive environment in } \\
\text { the community. Inadequate accommo- } \\
\text { dation leading to over crowding. }\end{array}$ & \\
\hline
\end{tabular}

the research respondents, researcher and the independent co-order will be able to communicate meaningfully in these languages.

- $\quad$ All research respondents gave their consent to participate out of their own free will.

Access to the family members was through the parliamentarian in the township, members of the Rate Payers Association, the station commander and also the individuals in charge or breadwinners in each family. The research sample comprised five families. There were six to eight family members that formed each focus group discussion. All the families came from the specific township where the research was conducted.

Members of each focus group discussion included parents, namely mother and father and also brothers and sisters of the adolescents who were no longer at the adolescent stage and who were also referred to as family members. All the focus group discussions were conduced in English, because the parents and family members were literate enough to speak English.

\section{Measures to Ensure Trustworthiness}

Measures to ensure trustworthiness were applied. Guba's (Lincoln \& Guba, 1995:290-327) strategies of credibility, transferability and dependability were applied. Activities in achieving credibility were prolonged engagement in the field, keeping reflexive journals, the researcher's authority, triangulation, peer review and structural sampling. Dependability was achieved by a dense description of the data and purposive sampling. Transferability was achieved by a description of the method of data gathering, data analysis and interpretation. $\mathrm{Fi}$ nally, confirmability was achieved by ensuring an audit of the entire research process, reflexive analysis and triangulation.

\section{Ethical Measures}

Strict ethical measures were adhered to during this research. These included informed consent of the respondents' privacy, ensuring confidentiality and anonymity and providing the families with results (SANA, 1991:5).

\section{Discussion of the Results}

Data was collected through audiotaping family members' discussions on the everyday life of the adolescents. Table 1 reflects the main theme, categories, and subcategories that emanated from the opinions of families on the everyday life of adolescents in a specific township in Swaziland. These will now be discussed and supported by direct quotes from family members and a literature control. The main theme identified in this research was that adolescents' lives were disrupted due to the lack of a conducive and supportive environment in the family and the community.

\section{Disrupted adolescents' life related to the lack of a supportive and conducive environment in the family and community}

It was evident from the focus group in terviews that there were a lot of conflict and misunderstanding between parents and adolescents. As a result of these factors affecting the adolescent's life, the 
relationship between parents and their adolescents seemed to have been severely wounded. These factors were organised in this research as the main theme, categories and subcategories respectively. Regarding the adolescents' defiance towards their parents, one of the respondents stated that the life of adolescents was full of problems because adolescents were defiant to their parents.

"Life of the adolescents is full of problems. Adolescents do not want to take parents' advice. When parents try to tell the adolescents that this is not good to do, the adolescents tell their parents that they have their own rights which parents should respect."

Another respondent commenting on disrupted adolescents' life due to loss of traditional values as a result of Westernisation had this to say: "We are too Westernised. We have lost our cultural pride. Everything is now modern. We are now sitting with our children together watching films, even films for adults."

According to Gule (1993:240) the life of adolescents is regarded by many African families as the fundamental future of each and every family. Children, specifically adolescents, are expected to be well socialised so that they can leave home and lead a meaningful life. The adolescents are expected to provide social support to the elderly once they become adults. Disruptions in the adolescents' life imply that important functions and expectations supposed to be carried out by adolescents in families in the future, may not be fulfilled, leaving a sense of insecurity and fear among parents about their future, which seems to hang in the balance.

Bee (1996:375) also stated that children from neglectful families exhibit the highest rate of problematic behaviour and poor achievement at school.

\section{Adolescents presented ineffective communication patterns due to lack of support from their parents}

Ineffective communication patterns in this research entailed the way adolescents communicated with their parents, which appeared to be unfavourable to the parents. Such communication was evidenced by the nature of the relationships that existed between parents and adolescents. Parents and family members stated that destructive curiosity, stubbornness, aggression and dangerous pride were the most prevailing responses they received from their adoles- cents.

One respondent commenting on parents' fears about their adolescents' life seemingly due to ineffective communication patterns, stated that parents had fears about individuals who became closely involved with their adolescents. Parents feared that such individuals could influence the adolescents to rebel against them: "Parents have fears about the adolescents' life because the parents do not know what happens in the adolescent's life. Who is this person with my child? Is he a good person or not? Should I allow my child to associate with him/her? is he not going to make my child turn against me? Will my child listen to me and also take my instructions if I tell her to move away from this person?"

Another respondent pointed out that adolescents did not want to listen to what their parents were telling them. Adolescents behaved as if parents knew nothing about their life: "The problem today with the adolescents is that they do not want to be told. ... adolescents behave as if parents know nothing or we never experienced the same thing. I think something must be done on the issue of children failing to listen to their parents."

The respondents also stressed that good communication between parents and their adolescents was important and that they should communicate with each other in good faith. The respondent stated that parents and adolescents were supposed to be good friends: "The way of approach and good communication is very important for adolescents and parents. Parents and adolescents should be good friends. They should communicate to each other and in good faith."

The adverse effects on the adolescents life due to ineffective communication patterns in the family was confirmed by Rice (1992:82) who stated that: “... when family influence decline, entertainment heroes and peers become increasingly important as models, especially in influencing verbal expressions, hair styles, musical tastes, clothing, and basic social values."

Perko and Kreigh (1990:130) stated that: "...communication concerns the type and patterns of dialogue that takes place either on an intra-psychic or interpersonal level. Openness and honesty promote objectivity. Objectivity, in turn, lends clarity to the issue, legitimacy to the power, and provides an opportunity to creatively address and satisfy the presenting need".

These ineffective communication patterns that exist between parents and their adolescents often lead to many problems, and these will be discussed as follows:

\section{- Destructive curiosity}

The overprotection by parents of adolescents lead to the adolescents displaying negative behaviour towards the parents. This display demonstrated by adolescents was in the form of destructive curiosity and stubbornness. Parents, family members and adolescents, stated that some parents were over-protecting their adolescents, that parents were not helping their adolescents develop properly. One respondent commenting on destructive curiosity that often lead to misunderstanding between adolescents and parents, said: "The over-protection may also cause curiosity in the adolescents' life leading to some misunderstanding of the world around them."

In view of the above Cicchetti and Carlson (1990:693) stated that: “...parents who cater to every need may engender resentment in the adolescent if they are viewed as being overly protective or overly indulgent or overly detached. Adolescents may resent this babying approach as their contact with the world beyond the family increase." In addition Cicchetti and Carlson (1990:693) added: "...conflict of all kinds during adolescence is found more frequently in authoritarian or permissive homes than in authoritative homes. The autocratically controlled adolescent is likely to harbour resentfulness toward the parents and is less likely to identify with them."

\section{Stubbornness}

Stubbornness in this research reflects a situation in which adolescents' behaviour was not polite towards their parents. This was also caused by over-protection by the parents. One respondent stated that parents' over-protection of their adolescents made the adolescents stubborn: "The over-protection from parents make adolescents to become stubborn. The more parents say no the worse the adolescents push for their rights."

\section{- Aggression}

Aggression in this research reflects a situation in which adolescents picked a quarrel with their parents without provocation. It seemed that adolescents felt that they did not have a voice in their families, i.e. adolescents' perceptions, feelings and thoughts were not heard and attended to by their parents due to ineffective communication patterns. One respondent commenting on adolescents' aggression due to lack of effective communication, resulting in poor relationships between parents and adolescents, said: "The poor relationship that exists between adolescents and parents due to lack of good communication be- 
tween the two parties, makes the adolescents move away from their parents. These adolescents then become aggressive to us as parents, because they want to do what they want, against the parents' will. Adolescents are very impatient. They do not tolerate situations. I think they need parents who can understand them when they are at this stage."

This kind of crisis which seems to exist between parents and their adolescents is supported by Rice (1992:101) who stated that parents and adolescents affected one another. Adolescents were influenced by the quality of support and communication from their parents, and parents were affected by their relationship with their adolescents and the way adolescents behaved towards them. Goldenberg \& Goldenburg (1996:39) confirm the above.

\section{Dangerous pride}

Dangerous pride in this research refers to the adolescents' perceptions of being more important than other people, especially demonstrating this attitude towards their parents. Parents and family members also stated that adolescents were not well informed about the biological development of their bodies nor about the importance of hard work to prepare for their own future. This deficit was seen to have lead to adolescents becoming very proud of themselves.

One respondent referring to this, stated that adolescents reach the adolescent stage at a time when they are uninformed about it: "In most cases, adolescents get into the adolescence stage, having not been informed about it. They then experience some physical development of their certain body parts which makes them become very proud about themselves."

Another respondent, commenting on adolescents' pride as a source of sour relationship between parents and adolescents, as well as adolescents' failure to attain a good future, said: "Our adolescents are not serious with their future. Instead of working very hard, they become proud of themselves. They have no interest at all in doing good things...some of the adolescents at this stage become aggressive and violent, and this is what makes the relationship between parents and adolescents become very sour."

Cicchetti and Carlson (1990:693) observed that the sour relationship that seemingly exist between parents and adolescents was due to the adolescents' "... power to stimulate and influence family conflict, to leave the family situation, to harm self and others, to embarrass their parents, to compare parents and other adults. ... Enhanced power that comes with adolescence is often a destabilising force, particularly when parents and/or adolescents have little motive or facility for flexible negotiation and compromise."

\section{Adolescents engage into risky lifestyles due to a lack of support and healthy relationships with their parents}

Parents and family members, as respondents in this research, stated that the adolescents were involved in risky behaviour because a number of these adolescents were already abusing drugs, have sexually transmitted diseases, are dying of AIDS and often attempt and/or successfully commit suicide.

One of the respondents stated that adolescent behaviour was bad. According to the respondents, adolescents claimed that they were allowed to have sex, drink alcohol and also abuse drugs: "The behaviour of adolescents is very bad. These young people they claim to be allowed to do things like enjoying sex, drinking alcohol, abusing drugs and many other things dangerous to them and these young adolescents are abusing a/cohol and drugs. I think it is even becoming late for parents to act fast to help the adolescents to grow properly."

In view of the above WHO (1991:11) states that "all young people face a variety of changes, requiring them to try new behaviours and develop new skills. This involves taking certain risks, which can be constructive or detrimental. Excessive risk taking can damage both short and long term health." Gordon (1996:566) adds to this by observing that risk-taking among adolescents results in "problems as diverse as substance abuse, violence and other destructive decisions the adolescents engage in, which turn out to be detrimental and destructive to the adolescent's life."

\section{ency \\ Drug abuse and drug depend-}

The research respondents also stated that drug abuse and-dependency were seriously destroying the adolescents' life in the specific township. One respondent commenting on parties that most often cause adolescents to abuse drugs, become dependent on the drugs, which make them become insane and then start wandering in the streets of the specific township, said: "In most cases you find that, if adolescents are not guided, they will always wait to push for parties which can lead the adolescents to drug abuse and drug dependency.

And at this stage a number of these adolescents abusing drugs become insane and then start wondering in the streets aimlessly and some parents give too much money to the adolescents which the adolescents use to buy drugs." Another stated: "Many families here are abusing drugs. The children from such families are destroying our families. As long as our children are not strong enough to resist the temptations outside, our out-cry will not be over."

Desjarlais et al (1995:102) emphasising the dangers of drug use in families, state: “... drug use is associated with family violence, child abuse, suicide, property crime, and gang violence. Dysfunctional families often force children to move away from home to value behaviours against the conventional society. These youngsters often feel rejected by abusive parents and join groups in which they feel accepted, "bad" is "good" membership in these groups frequently involved in the use of drugs."

Cosad (1998:4) in her study confirmed substance abuse in ten tertiary educational institutions in Swaziland, and reported that from a total of 2253 male students $49.4 \%$ abused beer, $37.3 \%$ wine, $31.1 \%$ abused home brew and $26.1 \%$ abused sprits.

Pregnancy, HIV/AIDS, sexually transmitted diseases (STD's)

Research respondents were concerned about the rate at which their adolescents were falling pregnant, contracting HIV/ AIDS and also contracting sexually transmitted diseases.

One respondent stated that adolescents demanded to be allowed to go to movies with their friends. According to the respondent this is what most often leads to adolescents becoming pregnant, contracting HIV/AIDS and sexually transmitted diseases: "When children get to the adolescent stage, they demand the right to go out with their peers to see movies which in most cases results in them becoming pregnant, getting HIVIAIDS and sexually transmitted diseases." Another said: "If these adolescents are involved in sex making, they will get sexual transmitted diseases such as AIDS. The girls become pregnant. A number of the adolescents are already dying of AIDS in this country, more especially in this community."

In view of the above WHO (1994:10) stated that: "... adolescents have a higher risk of suffering the consequences of early sexual exposure such as unplanned pregnancies, STD's and HIVIAIDS." Underlining this point, parents also stated 
that their adolescents were indiscriminately involved in sexual and immoral behaviour.

Gordon (1996:564) adds by saying: "pregnancy may become a threat to the life of the adolescents, and more especially to the adolescents' future because pregnancy tends to affect the performance of the pregnant adolescent at school." Gordon further stated that apart from the poor performance at school, adolescents involved in sexual activities might end up contracting HIV/AIDS and other sexually transmitted diseases and ultimately death.

\section{Suicidal thoughts}

Suicidal thoughts in this research refer to a situation where committing suicide or attempting to was becoming common among adolescents, and that parents and family members were worried about it. One respondent stated that it was becoming difficult for parents to punish their adolescents because the punished adolescents most often retaliate by attempting to commit suicide: "You punish an adolescent, that punishment will be followed by the adolescent committing suicide. This is the major problem parents are faced with, and this means we have to be careful how we deal with the adolescents."

Another respondent stated that committing suicide among adolescents was becoming a common habit, which usually occurred after the school results were made public. "Committing suicide has become a common habit among adolescents. Such bad habit usually occur immediately after the school results are out for the adolescents."

Rice (1992:299) confirming the problem of suicide among adolescents, states that: “...suicidal adolescents tend to come from disturbed family backgrounds. There may have been much conflict between the parents and between the parents and children. The parents may have manifested negative, rejecting attitudes toward the children. Suicide attempters often state that they do not feel close to any adult. There is no one to turn to when they need to talk to someone." Rice (1992:299) also confirmed that family problems or disruptions caused adolescents to be involved in suicidal thoughts.
Families unable to create a supportive and conducive environment for the adolescents due to their focus on own family stumbling blocks

The families' failure is due to the fact that parents are more focused on other family problems than assisting the adolescents to mobilise the available resources to promote, maintain and restore their own mental health.

One respondent describing and explaining one form of disruption of the adolescents' life stated that parents were perpetuating the disruptions in the adolescents' life: "Parents also are perpetuating the situation concerning adolescents. Parents nowadays kiss in front of the adolescents, a thing against our culture. Some parents even drink alcohol and abuse drugs in front of their children."

According to McGaha and Leoni $(1995: 475)$ "... the family is regarded by all known cultures as the fundamental social unit and is charged with the important task of socialising its members, more especially the young ones, so that human beings can continue to lead a meaningful life. Failure of parents to provide consistent love and nurturing, results in neglect of physical and emotional needs."

Parental ignorance, generation gaps, mass media (television, radio) were some of the specific issues observed in families by the research respondents to have aggravated the disruptions in the everyday life of adolescents, as stated in the parents' and family members' opinions on the everyday life of adolescents. This will now be discussed.

\section{Parental ignorance}

Parental ignorance in this research implies the situation in which parents are not knowledgeable enough to utilize the available resources to promote, maintain and restore the mental health of adolescents as integral part of their health and wholeness. Parents and family members, as respondents in this research, also stated that there was a lot of parental ignorance prevailing in families. Concerning parental ignorance, one re- spondent stated that adolescents were sometimes uninformed about their everyday life, they discover most of it on their own: "Sometimes the adolescents are not told about their everyday life. They discover most of the things ... on their own." and "I think we are now living in a changed society. There are a lot of changes occurring. I shall agree that our children are not well guided by the parents...to make things worse, some parents are not even aware that there are a lot of changes occurring in the life of the adolescents."

Rice (1992:391) on parental ignorance states: "Some parents are uninformed and do not know how to explain to their children. Other parents tell too little too late".

As a result of such knowledge deficit, a generation gap is created between adolescents and their parents.

\section{Disrupted adolescents' life re-} lated to a generation gap

One respondent stated that there was a gap that existed between parents and adolescents due to a lack of communication between parents and adolescents: "I think there is a gap between the parents and the adolescents which is caused by lack of communication between the two parties." In support of this observation Rice (1992:104) states: "Parent-adolescent misunderstanding arises from the two types of personalities of adults and youths. Parents feel that youths are crazy, reckless, and naive, too inexperienced even to recognise that they are foolish to take chances. Parents worry that their youths will have accidents, get hurt, or get in trouble with the law. Youths feel their parents are overly cautious and worry too much." The situation was worsened by the presence of mass media communication, which had a bad external influence on adolescents.

Disrupted adolescents' life related to bad influence of mass media communication

Mass media communication was also observed by the parents and family members as a serious destructive external factor which contributed to the disruptions in the adolescents' life. As a result one respondent stated that televi-

\section{“Young girls are falling pregnant and dropping out of school. Boys are pushing and/or abusing drugs. Parents are complaining about their adolescents, who do not respect them."}


sion, films and friends were bad influences in the everyday life of adolescents: "The television, film and friends are a bad influence to the adolescents."

Rice (1992:480) observes that: “...television can have a significant impact on adolescents in the formation of value systems, and behaviour...even a single thirty-minute exposure to television could significantly alter basic beliefs, attitudes, and the behaviour of large numbers of people for at least several months."

\section{Non-availahility of recreational centres related to the lack of a supportive and conducive environment in the \\ community}

Non-availability of recreational activities or centres in this research refer to a situation in which adolescents do not have a sports centre where the adolescents could occupy themselves by playing different games in sport when free. The research respondents also stated that the community in which this research was conducted was not organised in terms of facilities or recreational activities/centres, which could keep adolescents occupied. Hence, idleness and criminal offence were becoming the order of the day in the township.

Idleness and criminal offence Idleness and criminal offence in this research symbolise a situation in which adolescents are unoccupied, hence wandering in the township streets. Adolescents, according to the respondents, were supposed to be assisted by the community to help themselves, not to get involved in crime.

One research respondent stated: "The community should be organised. The community should be in a position to assist the adolescents to help themselves, so that the adolescents do not idle in the streets of the township, and also that they are not involved in crime."

Another respondent suggested that social clubs for parents and adolescents are formed in order for parents to hold discussions with their adolescents: "I think we should form parents and adolescents' social clubs where parents would be able to discuss with the adolescents. The recreational centre therefore, should provide such chances for parents and adolescents to meet. And if this is done well, it should help the adolescents to become responsible people in this township."

Manning (1996:113) in view of the above, stated that: “... factors contributing to the increase of crime among adolescents included a rising level of divorce, unemployment, effects of television, the increase in proportion of working mothers and also the increase in the number of children wandering in streets of the city, after dropping out of school."

\section{Inadequate \\ accommodation}

Parents and family members as respondents in this research expressed their concern that the township was overcrowded: "In this community we are overcrowded. There are too many people with different backgrounds. So in this situation our adolescents mix together with adolescents from different homes. You alone, you will not succeed in dealing with your own adolescents only."

Another respondent stated that parents were supposed to take a proactive role in helping their adolescents become aware of destructive factors to the adolescents' everyday life which were prevailing in the township: "Parents should not just fold their arms and watch their adolescents being destroyed by the bad things around..."

As a result of the disruptions in the adolescents' life, respondents in this research made some recommendations for the purpose of promoting the adolescents' life in the township in Swaziland. These recommendations are integrated with the guidelines, as discussed below.

\section{Recommendations [Guidelines] for the Advanced Psychiatric Nurse Practitioner}

This research highlighted the physical, mental, social, and spiritual related problems regarding the everyday life of the adolescents. It was also clearly indicated that families and the community at large were unable to mobilise the available resources to promote, maintain and restore the mental health of the adolescent. The results of this research clearly necessitated the need for advanced psychiatric nurse practitioners and other health professionals to assist families and the community to effectively mobilise the available resources to promote, maintain and restore the mental health of adolescents.

In view of the above conclusions, the following guidelines for operationalisation are recommended and Figure 1 depicts a conceptual framework for the reintegration of healthy adolescents into the community. This framework will serve as the basis for description of guidelines to integrate a mentally healthy adolescent into the community.

\section{Euidelines to address disrupted adolescents' life related to the lack of a supportive environment in the family and community}

The disrupted adolescents' life can be addressed by modifying the presented deficiency of ineffective communication among adolescents and their parents. The appropriate strategy for psychiatric nurse practitioners would be to use a holistic approach at any level of intervention. The strength of this strategy lies in its ability to adequately preserve the dignity of the individual adolescent by recognising the relationship between his/ her internal and external environments (Stuart \& Sundeen, 1995: 200).

This means that the psychiatric nurse practitioners need to use the nursing process which will guide them to acknowledge the autonomy the parents and adolescents deserve regarding the freedom to make their own choices with regard to setting goals and the means by which these goals can be achieved in an effort to promote, maintain and restore the mental health of adolescents as integral part of adolescents' health and wholeness.

In this case the parents, adolescents and the psychiatric nurse practitioners will be involved in assessing needs, formulate objectives for intervention and imple mentation to achieve the objectives and also engage together into evaluation of effectiveness.

\section{Increasing the adolescents' support system}

Psychiatric nurse practitioners in primary health care and other health institutions, including those providing mental health services in the specific township, need to recognise that they also form the frontline support for these adolescents. The responsibility to widen the support system of the adulescents, especially in the specific township, lies with them.

The psychiatric nurse practitioners should also observe that a broad support-base can be provided to the adolescents by teachers, social workers, other health workers, the police force, non-governmental organisations and other parties interested in the issues affecting the everyday life of adolescents in the specific township and the country at large.

Vinson, Baldry and Hargreaves 


\section{nceptual framework for re-integration of adolescent's life into the community}

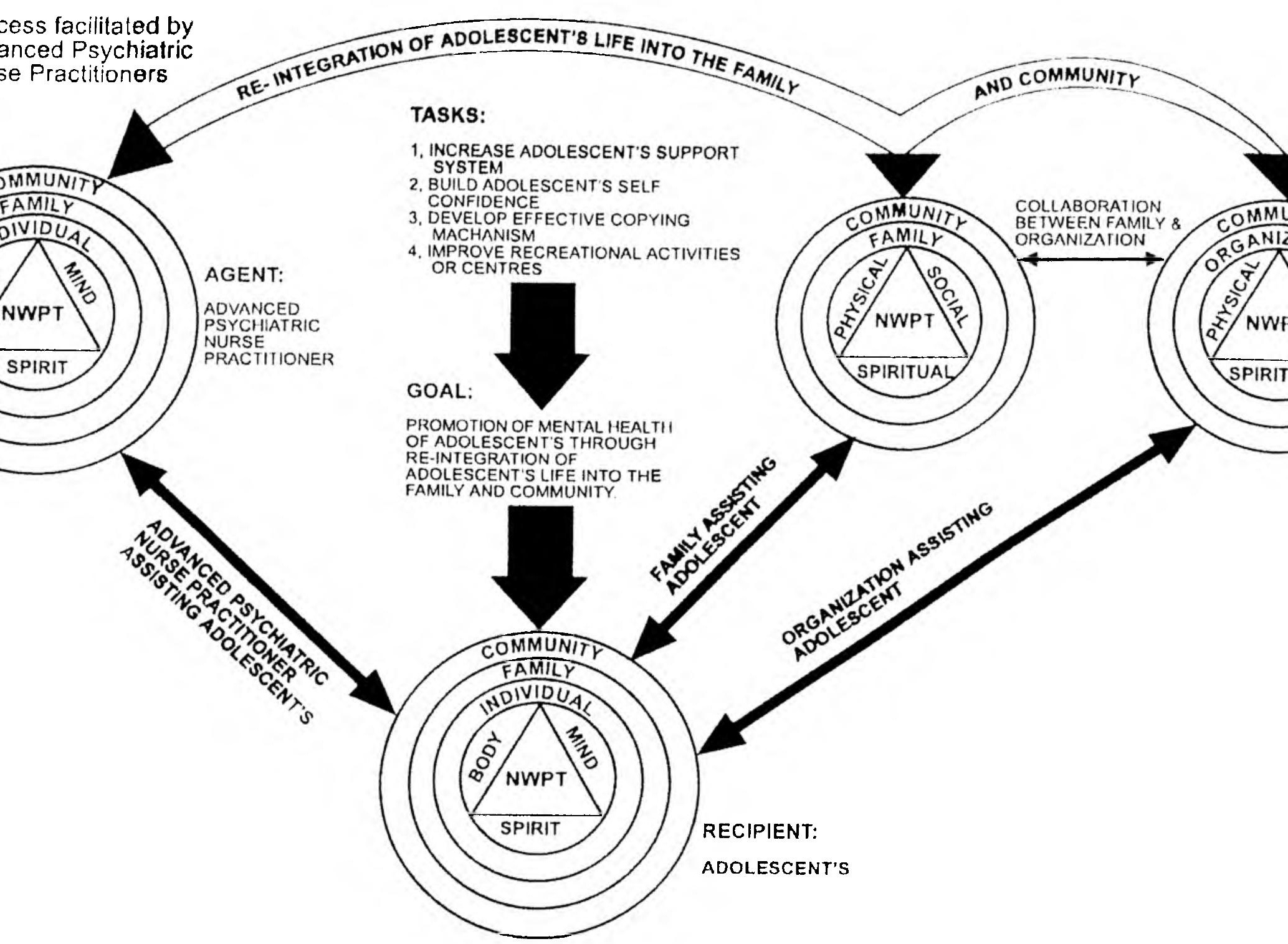

Is in this research because advanced psychiatric nurse practitioner (agent) will assist families and organisations to promote adolescent's 's life into the family and community. There will be collaboration between family and organisation or promotion of adolescent's mental health. 
(1996:523-543) state that social networks among professionals and nonprofessionals, including the adolescents, provide "natural social relationships" and that such networks serve the purpose of positive reinforcement required to change behaviour. For the adolescents in the township it can become their mediator in establishing contact with the larger community.

\section{Building adolescents' self- confidence}

Self-confidence is a factor linked directly to motivation and also serves as a force necessary to cast off negative and dangerous feelings of curiosity, stubbornness, aggression and pride by adolescents towards their parents.

The psychiatric nurse practitioner should give the adolescents an opportunity to develop new ways of dealing with their negative feelings of destructive curiosity, aggression, stubbornness and dangerous pride and replace them with feelings of possessiveness, responsibility and accountability towards their own lives. This will mean that advanced psychiatric nurse practitioners in their support of these adolescents, will assist them in developing meaningful, constructive and effective communication skills which will improve their patterns of interaction between the internal and external environments, to put in place a strong relationship with their parents, peer groups and others.

Building adolescents' confidence can also occur through individual and group psychotherapy. Group psychotherapy is recommended for its cost-effectiveness as well as for its power to reinstate the individual in his/her rightful social unit by fostering a sense of belonging. In groups, adolescents will be able to share their experiences and at the same time modify their abilities in coping skills or where necessary, do away with less effective coping skills.

\section{Developing effective coping mechanisms}

For the families, as with the adolescents, the advanced psychiatric nurse practitioners are to use the nursing process, which will also allow the direct participation of the parents and family members who are well informed about family issues contributing to the disruptions in the everyday life of the adolescents. According to Colapinto (1995:64-65) families do not always become passive victims of life threatening situations, but may view themselves as being inadequate.

Advanced psychiatric nurse practitioners will have to be open in their interventions by asking questions that will encourage the answering of questions by the family members regarding their feelings and within a context that will allow freedom of expression. The advanced psychiatric nurse practitioners facilitate the full participation of each of the families in the whole nursing process. This means that psychiatric nurse practitioners will allow the parents to acknowledge the existence of such life threatening elements, especially in the everyday life of the adolescents.

The researcher believes that parents' awareness of the descriptions in the adolescents' life will motivate them to put more effort into asserting their adolescents to develop coping mechanisms against destructive elements causing disruptions in the adolescents' life. Development of coping mechanisms among adolescents should be accomplished by making adolescents become aware of the fact that their lives are in danger. The researcher also believes that once adolescents are aware of the disruptions in their everyday life, they will be encouraged and motivated to avoid getting into situations causing disruptions to their everyday life, even if such situations are prevailing in families and the community.

In addition, advanced psychiatric nurse practitioners will be expected to allow the parents to formulate their own objectives after a proper realisation of present issues in each family. Designing a proper plan for implementation, and ultimately evaluating effectiveness will follow this.

\section{Improving the recreational facilities in the township}

The researcher believes that the establishment of collaborative and consultative meetings between advanced psychiatric nurse practitioners and organisations working with children, will facilitate the sharing of ideas regarding disruptions in the adolescents' life. The researcher is of the opinion that collaborative and consultative meetings between the two parties will create an opportunity for advanced psychiatric nurse practitioners to equip such organisations with additional strategies and skills, which the organisations can utilise to promote, maintain and restore the mental health of adolescents.

\section{Forming a complimentary relationship with the school counselling teachers}

Counselling services provided at schools, if strengthened, can become an important mental health service to assist adolescents whose everyday life is disrupted by the lack of supportive and con- ductive environments in the family and community. Advanced psychiatric nurse practitioners should establish a good working relationship with the counselling teachers at schools.

The researcher is of the opinion that the establishment of frequent consultative meetings between the advanced psychiatric nurse practitioners and counselling teachers will improve the working relationship between the two parties. The good working relationship between the advanced psychiatric nurse practitioners and counselling teachers will create an opportunity for the advanced psychiatric nurse practitioners to share some of the psychotherapeutic techniques used in psychiatric nursing, which could be utilised by the counselling teachers to promote, maintain and restore the mental health of the adolescents.

According to Kaplan, Sadock and Grebb (1994:1135) "remedial, educational and patterning psychotherapy endeavour to teach new attitudes and patterns of behaviour to children who persist in using immature and inefficient patterns, which are often presumed to be due to a maturational lag."

\section{Conclusion}

The urgent need to promote, maintain and restore the mental health of the adolescent, as reflected in the research findings, necessitated the need for advanced psychiatric nurse practitioners to become directly involved in assisting adolescents to promote, maintain and restore their mental health as integral part of health and wholeness. In the research findings it was further reflected that it was important to mobilise the townships so that it would be supportive and conducive to the everyday life of the adolescents. The future of any community and/or country has in its hand the good mental health of adolescents and likewise the future of this township. 


\section{Bibliography}

BEE, H. 1996. The developing child. Mexico City: Longman.

BOTES, A.C. 1991. A functional approach in nursing. Johannesburg: Rand Afrikaans University.

BURNS, N., \& GROVE, S.K. 1993. The practice of research, conduct, critique and utilisation. Philadelphia: Sage.

CICCHETTI, D., \& CARLSON, V. 1990. Child maltreatment. Cambridge: Cambridge University Press.

COLAPINTO, J.A. 1995. Volition of family process in social services. Implication for treatment of neglectful families. Family Process (34):59-73

COSAD. 1998. The prevalence of tobacco, alcohol and drug consumption among Swaziland High School and Tertiary Institution students. Manzini: Unpublished research.

CRESWELL, J. 1994. Research design: Qualitative and quantitative approaches. London: Sage.

DENZIN, N.K., \& LINCOLN, Y.S. 1994. Handbook of qualitative research. Thousand Oaks: Sage.

DESJARLAIS, R., EISENBERG, L., GOOD, B., \& KLEINMAN, A. 1995. World mental health: Problems and priorities in low-income countries. New York: Oxford University Press.

GULE, G. 1993. Socio-cultural constraints to family planning in Swaziland. Africa Insight 23 (4).

GOLDENBERG, I., \& GOLDENBERG, H. 1996. Family therapy: An overview. New York: Brooks/Cole Publishing Company.

GORDON, P. 1996. Adolescent decision making: A broadly based theory and its application to the prevention of early pregnancy. Adolescence 31:123.

HOLLOWAY, I., \& WHEELER, S. 1996. Qualitative Research for Nurses. London: Hartnolls Ltd.

KAPLAN, H.I., SADOCK, B.J., \& GREBB, J.A. 1994. Synopsis of psychiatry: Behavioural science: Clinical psychiatry. Seventh edition. Baltimore: Williams and Wilkens.

LINCOLN, Y.S., \& GUBA, E.G. 1985. Naturalistic enquiry. California: Sage.

MANNING, N. 1996. Social problems and welfare ideology. England: Gower Publishing Company Limited.

McGAHA, J.E. \& LEONI, E.L. 1995. Family violence, abuse and related family issues of incarcerated delinquents with alcoholic parents compared to those with non-alcoholic parents. Adolescence 30:118, Summer.

MORSE, J.M. 1994. Critical issues in qualitative research methods. London: Sage Publications.

MOUTON, J. \& MARAIS, H.C. 1990. Basic concepts in methodology of social sciences. RSA: Human Science Research Council.

ORAL ROBERTS UNIVERSITY: ANNA VAUGHN SCHOOL OF NURSING. 1990. Self-study report submitted to the council of Baccalaureate and higher degree programmes, National League for Nursing, August 1990 . Volume 1. Narrative by criteria. Tulsa, Oklahoma: Oral Roberts University: Anna Vaughn School of Nursing.

PERKO, E. \& KREIGH, Z. 1990. Psychiatric and mental health nursing. Republic of Singapore: Prentice Hall. 
POLIT, F., \& HUNGLER, P. 1995. Nursing research: Principles and methods. Philadelphia: Lippincott Company.

QUINTON, J.C. 1991. Values across the curriculum. London: Falmer Press

RICE, F. 1992. The adolescent development, relationships and culture. Massachusetts: Allyn and Bacon.

SOUTH AFRICAN NURSING ASSOCIATION. 1991. Ethical standards for nurse researchers. Pretoria: The South African Nursing Association.

STUART, S., \& SUNDEEN, J. 1995. Principles and practise of psychiatric nursing. St Louis: Mosby.

VINSON, T., BALDRY, E., \& HARGREAVES, J. 1996. Neighbourhoods, networks and child abuse. British Association of Social Workers (26):523-542.

WHO \& UNFPA. 1994. Young people's health and development. Lesotho: WHO.

WHO. 1991. Approach to adolescent health and development: Principles for success. Geneva: WHO/ADH/92.3 Distr. Limited.

WILSON, H.S. 1989. Research in nursing. California: Addison-Wesley Co. 